\title{
Do you know this syndrome?
}

\author{
Você conhece esta síndrome?
}

\author{
Denise Steiner ${ }^{1}$ \\ André César Antiori Freire Pessanha ${ }^{2}$ \\ Camila Feola ${ }^{2}$
}

\section{CASE REPORT}

A 16-year-old male (RFDS) presented himself to our outpatient clinic complaining of having patches on the body for a year. He stated that the patches started on the right shoulder and then progressively spread to other parts of the body. He denied associated symptoms. There was no personal or family history worthy of note. A physical examination revealed irregular brownish hyperchromic patches with asymmetric hair growth of 5 to $15 \mathrm{~cm}$ in diameter, distributed on the front and back parts of the shoulders bilaterally, right side of the neck,

\author{
Fernanda Ayres de Morais e Silva ${ }^{2}$ \\ Nediana Bialeski ${ }^{2}$ \\ Carla Arantes Bertolucci Buzzoni ${ }^{3}$
}

umbilical region of the left hemisphere of the body (Figure 1) and posterior left thigh (Figure 2). We also observed bilateral breast hypoplasia, pectus excavatum and scoliosis. A biopsy revealed acanthosis and papillomatosis with hyperpigmentation of the basal layer, consistent with Becker's nevus (Figure 3). $\mathrm{X}$-ray of the spine: severe thoracolumbar lateral curvature, vertebral rotation and rib rotation. Breast ultrasound: reduced number of glands on both sides. Becker nevus syndrome was diagnosed.

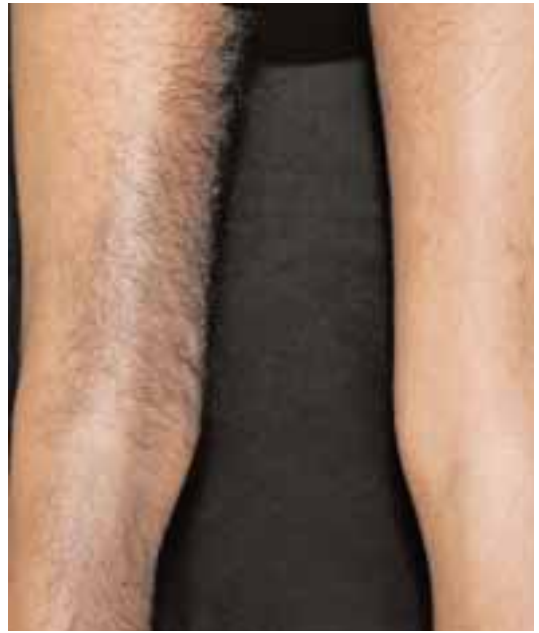

Figure 2: Hairy brownish patch on the posterior left thigh

\footnotetext{
Approved by the Editorial Board and accepted for publication on 31.10.2008

* Work conducted at the Department of Dermatology - University of Mogi das Cruzes (UMC) - Sao Paulo (SP), Brazil. Conflict of interest: None / Conflito de interesse: Nenbum

Financial funding: None / Suporte financeiro: Nenhum

1 PhD in Dermatology, Head of Medical Residency in Dermatology, University of Mogi das Cruzes (UMC) - Sao Paulo (SP), Brazil. Resident Physician in Dermatology, University of Mogi das Cruzes (UMC) - Sao Paulo (SP), Brazil.

Dermatologist - Brazilian Society of Dermatology - Sao Paulo (SP), Brazil.

(C)2011 by Anais Brasileiros de Dermatologia
}

FigURE 3: Biopsy of lesion on the right shoulder: acanthosis and papillomatosis with hyperpigmentation of the basal layer

Figure 1:

Hairy brownthe umbilical t hemi-

sphere of the body 


\section{DISCUSSION}

Becker's nevus, also called Becker's melanosis and Becker's pigmentary hamartoma, was first described in 1949 by William Becker, who reported the presence of unilateral hyperchromic skin lesions with hair in two young male patients. ${ }^{1,2,3}$

Becker's nevus is a hyperchromic brownish well-demarcated hairy patch which is usually single and located on the shoulders, anterior chest or scapular region. It is more frequent in men (2-5:1) and develops in the peripubertal period, when it increases slowly and irregularly, acquiring a geometric configuration and becoming persistent and assimetric.1,2,4 Its prevalence is not known, but a study involving 19,302 men (17-26 years old) showed that it is close to $0.52 \% .5$ Hair density may be variable and may even be absent. In $5 \%$ of the cases, it is itchy, and in $25 \%$ there is a history of severe sunburn prior to the lesion, in addition to a strong association with smooth muscle hamartoma. ${ }^{1}$

Its etiopathogenesis is unknown. Becker's nevus is considered a hamartoma of ecto-mesodermal tissues, appearing sporadically by cutaneous mosaicism; however, autosomal dominant inheritance with incomplete penetrance has been documented. ${ }^{6,7}$ It is considered a functional androgen-dependent tumor due to several factors: higher incidence in males, pubertal development, hypertrichosis, association with intralesional acne and anomalous scrotum, in addition to an increased number of androgen receptors and messenger RNA in the site of the lesion. ${ }^{1,6}$ Its association with pityriasis versicolor has also been reported, since Pityrosporum orbiculare develops easily in an area with a lot of sebaceous follicles. ${ }^{8}$

In 1997, Koopman and Happle reviewed 23 cases in which Becker's nevus was associated with breast hypoplasia and other muscle, skin or bone changes ipsilateral to the nevus, which they called Becker nevus syndrome. ${ }^{9}$

This syndrome is the association of Becker's nevus with breast hypoplasia and other anomalies; the most frequent ones are lumbar spina bifida, thoracic scoliosis and pectus carinatum, always ipsilateral to the lesion. Its frequency is higher in women (1.5:1), probably because it is easier to diagnose breast hypoplasia in women. ${ }^{1,9}$

The lesions associated with the syndrome are hypoplastic. This could be explained by the fact that the development of breasts, nipples and areolas at puberty is primarily estrogen-dependent in both sexes. Thus, the excess of androgen receptors in the Becker's nevus counterbalances the effect of the estrogen, leading to the appearance of hypoplastic lesions. However, the musculoskeletal abnormalities are not explained by this mechanism. ${ }^{10}$

An anatomopathological examination shows mild acanthosis and papillomatosis with hyperpigmentation of the basal layer. An electron microscopy reveals an increased number of melanosomes in melanocytes, increased number and size of melanosome complexes in keratinocytes and increased expression of testosterone receptors. ${ }^{1,11}$

Its evolution is benign, pigmentation stabilizes in 1 to 2 years and rarely regresses. Hair growth follows the onset of pigmentation and persists with development of thick hair. ${ }^{1}$

Treatment with surgical excision is limited due to the length of the patch. There are reports according to which Q-switched ruby laser (694 $\mathrm{nm})$ and Erbium: YAG ${ }^{12}$ promote selective damage of superficial melanocytes. However, recurrences may occur due to the depth of the hair follicle with its pigmented keratinocytes and melanocytes containing large melanosomes, which would serve as a reservoir for repigmentation. Jung et al ${ }^{13}$ reported improvement of the hypoplastic breast with the use of spironolactone for 4 weeks, but more studies are needed. ${ }^{14}$

\section{ACKNOWLEDGEMENT}

The authors thank Dr Marco Antonio

Soufen, the pathologist who helped to conduct and analyze the anatomopathological examination. 
Abstract: Becker nevus syndrome is the association of Becker's nevus with breast hypoplasia and other ipsilateral bone or muscle changes. It is considered to be a hormone-dependent disorder caused by a disturbance in the activity of the androgen receptor that appears to be increased in Becker's nevus, which may influence the development of associated lesions. We present a relevant case of this syndrome due to the rare systematization of the lesions in addition to the exuberant extracutaneous involvement in this case.

Key-words: Hamartoma; Nevus; Receptors, Androgen

Resuimo: A síndrome do Nevo de Becker consiste na associação do nevo de Becker com hipoplasia mamária e outras alterações ósseas ou musculares ipsilaterais a lesão. È considerada desordem hormônio dependente causada pelo distúrbio na atividade do receptor de androgênios que parece estar aumentado no nevo de Becker podendo influenciar no desenvolvimento das lesões associadas. Apresentamos um caso relevante desta síndrome pela raridade da sistematização das lesões, além do exuberante acometimento extracutâneo neste caso.

Palavras-chave: Hamartoma; Nevo; Receptores androgênicos

\section{REFERENCES}

1. Danarti R, Konig A, Salhi A, Bittar M, Happle R. Becker's nevus syndrome revisited. J Am Acad Dermatol. 2004;51:965-9.

2. Sladewski S, Pietropaolo N, Sigüenza N, Cabrera H, García S. Nevo de Becker: a propósito de 15 casos. Dermatol argent. 1997;3:208-14.

3. Alfaro A, Torrelo A, Hernández A, Zambrano A, Happle R. Becker nevus syndrome. Actas Dermosifiliogr. 2007;98:624-6.

4. Khatami A, Seradj MH, Gorouhi F, Firooz A, Dowlati Y. Giant bilateral becker nevus: a rare presentation. Pediatr Dermatol. 2008:25:47-51.

5. Tymen R, Forestier JF, Boutet B, Colomb B. Nevus Tardif de Becker. Ann Dermatol Venerol. 1981;108:41-6.

6. Chapel TA, Tavafoghi V, Mehregan A, Gagliardi C. Becker's melanosis: An organoid hamartoma. Cutis 1981;21:405-15.

7. Happle R. Mosaicism in human skin: understanding the patterns and mechanisms. Arch Dermatol 1993;129:1460-70.

8. Trope BM, Assis TL de, Marques AS. Pitiríase versicolor - atualização bibliográfica. An Bras dermatol $1992 ; 67: 159-166$.

9. Happle R, Koopman RJ. Becker nevus syndrome. Am J Med Genet 1997;68:357-61.

10. Person JR, Longcope C. Becker's nevus: an androgen-mediated hyperplasia with increased androgen receptors. J Am Acad Dermatol 1984;10:235-8.

11. Sarpa HG, Harris R, Hansen CD, Duffin KPC, Florell SR, Hadley ML. Androgen receptor expression patterns in Becker's nevi: An immunohistochemical study. Am Acad of Dermatol. 2008;59:834-8.
12. Martins M. laser Erbium:YAG no tratamento de nevos melanocíticos. An Bras Dermatol. 2008;83:533-7.

13. Glaich AS, Goldberg LH, Dai T, Kunishige JH, Friedman PM. Fractional resurfacing: a new therapeutic modality for Becker's nevus. Arch Dermatol. 2007;143:1488-90.

14. Jung JH, Kim YC, Park HJ, Clinn YW. Becker's nevus with ipsilateral breast hypoplasia: improvement with spironolactone. J Dermatol. 2003;30:154-6.

How to cite this article/Como citar este artigo: Steiner D, Silva FAM, Buzzoni CAB, Bialeski N, Feola C, Pesanha. Do you know this syndrome? Becker Nevus Syndrome: Case Report. An Bras Dermatol. 2011;86(1):165-72. 